\title{
USE OF EXPANDED CRITERIA IN LIVING KIDNEY DONORS - THE CRUCIAL FACTOR FOR IMPROVEMENT OF THE KIDNEY TRANSPLANT PROGRAMME IN REPUBLIC OF MACEDONIA
}

\author{
Zivko Popov $^{1}$, Perko Kolevski², Ninoslav Ivanovski ${ }^{3}$ \\ ${ }^{1}$ Macedonian Academy of Science and Arts, Skopje, R. Macedonia \\ 2 Institute for Transfusion Medicine, Ss. Cyril and Methodius University, Skopje, R. Macedonia \\ ${ }^{3}$ University Nephrology Clinic, Ss. Cyril and Methodius University, Skopje, R. Macedonia
}

Corresponding Author: Zivko Popov, Macedonian Academy of Sciences and Arts, Bul. Krste Misirkov br. 2, 1000 Skopje, R. Macedonia, Tel: + 389 (0)2 32354 00, Fax: + 389 (0)2 32355 00, E-mail: zivkopopov2000@yahoo.com

\begin{abstract}
Renal transplantation is surely the best treatment for Chronic Kidney Disease (CKD) patients in both developed and developing countries. Due to the tragic events in former Yugoslavia at the beginning of the nineties, it was not possible to develop a really good clinical practice in the field of transplantation. Facing the lack of Deceased Donor Donation Transplantation and any organ-sharing among the Balkan countries, we introduced a large and very ambitious living donor transplant programme including what were called expanded criteria living donors. In the period of the past 20 years elderly (above 65 years), unrelated (emotionally related), marginal and ABO incompatible living donors were accepted. Due to the skilled surgical team, powerful immunosupression and HLA compatibility testing, the results were promising and the number of complications very low. The authors concluded that use of an expanded criteria living donor is fully acceptable, especially in developing countries, and could ameliorate the severe organ shortage in the region.
\end{abstract}

Key words: kidney transplant, living expanded criteria donors, graft and patients survival rate, complications.

There is not any doubt that renal transplantation is the best option for the treatment of Chronic Kidney Disease (CKD) patients in both developed and developing countries. The Kidney Transplant Programme in Macedonia started in 1977, when the first two living donor transplants were performed with the assistance of colleagues from the Clinical Centre in Rijeka (Croatia). But real organized renal transplanttation with an authentic Macedonian transplant team started in 1987 with the use of deceased brain death donors following all the necessary procedures and after getting written permission for organ removal from the family members. At that time the very enthusiastic Macedonian transplant team educated in France performed
17 renal transplants from deceased donors over a period of 18 months. Furthermore 7 kidneys were allocated to different transplant centres in Former Yugoslavia (Belgrade, Rijeka, Ljubljana) which was the first real organ sharing in our former country. Due to the tragic events in the former Yugoslavia at the beginning of the nineties, further development of the real renal transplant programme was not possible. Facing the lack of organized deceased donor transplanttation in the whole region over the past 20 years, we introduced an ambitious living donor transplant programme accepting from the very beginning so-called expanded criteria living donors including marginal, elderly, emotionally related and ABO incompatible donors [1-8]. Thus, we 
could continue our transplant activity in the country during the past very turbulent period of 25 years. In the meantime the first official Kidney Transplant Centre was founded in the Urology Clinic. The usual number of transplants in the last decade was between 16 and 20 per year, with substantial success and safety for the donors and recipients. The surgical technique, the posttransplant immunological and clinical monitorring was already very well established many years ago. The appropriate HLA matching, Complement Depending Cytotoxicity (CDC) cross match and powerful quadruple sequential immunosuppression enabled very good patient and graft survival rates. Due to the well-educated surgical team the number of surgical complications was very low, corresponding to the best urological practice in western European countries [9, 10]. In the meantime the transplant team was enlarged with more nephrologists, urologists and immunologists, and we were able to continue to use the expanded criteria living donors as our own original experience. Most of our original work was published and/or presented at the most prestigious international transplant meetings all over the world [11-13].

The reason for the recent increase in living donor transplantation (24 in 2012 and 35 in 2013) in Macedonia might be explained by the fact that the majority of Living Donor pairs were already well prepared exactly according to the policy of accepting the expanded criteria living donors. Thus, analysing the recently performed transplantations in the country we can conclude that 15 donors belonged to the group of elderly donors ( $>65$ years) which was the policy introduced into Macedonian transplant practice 25 years ago [1, 2, 4]. On the other hand 11 donors were non-related (predominantly spousal) and approximately one half of the living donors were accepted according to the criteria of marginal donors (mild to moderate hypertension, two or multiple renal arteries) which was also already established policy in our centre [3, 6, 8].

But there is not any substantial increase in kidney transplantation anywhere without welldeveloped deceased donor transplantation. Hence, any discussion about the numbers of 20,24 ,
30 even 35 transplants (10 to 17 per million inhabitants!!) per year is simply ridiculous. Bearing in mind that at the moment there are 19 haemodialysis centres with about 1500 patients in Macedonia, the above-mentioned numbers of transplants are very far from sufficient. Thus the real challenge for all transplant professionals in the region is the introduction of a deceased donor donation programme using at first the Croatian experience with the help of the South Eastern Europe Health Network (SEEHN), the Transplantation Society (TTS) and the European Society for Organ Transplantation (ESOT). The initiative started in 2010 with a nomination of a National Focal Point (NFP), but unfortunately, until December 2013, did not have any success regarding our country. Three years later there was still not any deceased donor transplanttation in the country. Many productive and less productive meetings were held in the region but nothing happened. After recently changing our NFP, things have improved for the first time. We now have ambitious young people very well trained in European centres and, as a result of that, the first 4 deceased donor transplants were performed recently. In the meantime a National Transplant Coordinator has been nominated as well as a network of local coordinators. Finally the budget per transplant procedure DRG code from our Health Insurance Fund increased from 5000 Euros in 2011 to 16000 in 2014, which was a good base for further development of both living and deceased donor renal transplantation. Thus, with this important support from local authorities, the further improvement of our Transplant Programme became very possible. So, now it is time for real work! Good Luck!

\section{REFERENCES}

1. Popov Z, Ivanovski N, Kolevski P. Kidney Transplantation in Macedonia. Ann Urol. 2000; 34: 294-301.

2. Ivanovski N, Cakalroski K, Masin G, Polenakovic M, Popov Z, Kolevski P. Medical Risk and Benefit in Elderly Living Renal Donors- Our Experience. Transplant Proc. 1991; 23: 2626.

3. Rambabova-Busljetic I, Popov Z, Masin-Spasovska J, Sikole A, Selim Gj, Dohcev S, Ivanovski N. Could liiving unrelated renal transplantation ameliorate the 
actual shortage of organs in the Balkan region? Hippokratia. 2013; 17: 3243-324.

4. Ivanovski N, Masin J, Kolevski P, Stojceva-Taneva O, Popov Z. Use of Elderly Living Kidney Donors: Twenty Years' Experience in the Balkans. Transplant Proc. 2011; 43: 3415-3417.

5. Ivanovski N, Popov Z, Masin-Spasovska J, Dimcevska AH, Kolevski P. First two ABO-incompatible Living Renal Transplantations Using Splenectomy, Rituximab, Plasmapheresis and IVIG as a Preconditioning Regimen: A Single Center Experience in the Balkans. Xenotransplantation. 2006; 13: 123-125.

6. Ivanovski N, Popov Z, Kolevski P, Cakalaroski K, Masin J, Zafirovska K. Living Emotionally Related Renal Transplantation - Single Center Experience in the Balkans. Ann Transplant. 2004; 9: 48-49.

7. Ivanovski N, Popov Z, Kolevski P, Cakalaroski K, Stojkovski L, Spasovski G, Zafirovska K. Living Related Renal Transplantation - The Use of Advanced Age Donors. Clin Nephrol. 2001; 55: 309-312.

8. Ivanovski N, Popov Z, Kolevski P, Cakalaroski K, Stojkovski L. The Donor Organ Shortage in the Balkans: Accept Everyone! Transplant Proc. 1997; 29: 3397-3398.

9. Kolevski P, Popov Z, Hristova-Dimcevska A, Petrovski D, Cakalaroski K, Ivanovski N. Living Donors: immunological factors. Ann Urol. 2000; 34: 319-322.

10. Popov Z, Ivanovski N, Lekovski L, Stankov O, Dohcev S, Petrovski D, Cakalaroski K, Janculev J, Kolevski $\mathrm{P}$, Abbou C, Chopin D. Postoperative complications following kidney transplantation. Ann Urol. 2000; 34: 223-229.

11. Ivanovski N, Masin J, Dohcev S, Rambabova- Busljetic I, Pusevski V, Popov Z - Preemptive expanded criteria living donor renal transplantation - first choice of treatment of ESRD on the Balkans - Transplantation. 2008 (Suppl), Vol 86, No 2S; 758-758.

12. Popov Z, Ivanovski N, Cakalaroski K, Kolevski P, Chopin D. Coelioscopic renal prelevement on living donor. The first four cases in Republic of Macedonia. Progres en urologie. 2005; 15: 1227-1228.

13. Ivanovski N, Rambabova-Busljetic I, Masin-Spasovska J, Dohcev S, Popov Z. Use of Expanded Criteria Living Donors: The Possible Solution of Severe Organ Shortage in the Balkans. $3^{\text {rd }}$ ELPAT Congress 2013. Book of Abstracts.
Резиме

\section{УПОТРЕБАТА НА ПРОШИРЕНИ \\ КРИТЕРИУМИ КАЈ ЖИВИ ДАРИТЕЛИ \\ НА БУБРЕГ - ПРЕСУДЕН ФАКТОР ЗА ПОДОБРУВАњЕ НА ПРОГРАМАТА ЗА БУБРЕЖНА ТРАНСПЛАНТАЦИЈА ВО РЕПУБЛИКА МАКЕДОНИЈА}

\section{Живко Попов ${ }^{1}$, Перко Колевски ${ }^{2}$, Нинослав Ивановски ${ }^{3}$}

${ }^{1}$ Македонска академија на науките и уметностите, Скопје, Р. Македонија

${ }^{2}$ Институт за трансфузиона медицина, Универзитет „Св. Кирил и Методиј“, Скопје, Р. Македонија

${ }^{3}$ Универзитетска клиника за нефрологија, Универзитет „Св. Кирил и Методиј“, Скопје, Р. Македонија

Бубрежната трансплантација претставува најдобар начин за лекување на хроничната бубрежна болест во развиените земји, како и во земјите во развој. Трагичните настани во поранешна Југославија во почетокот на деведесеттите години од минатиот век го оневозможија развојот на трансплантацијата како медицинска процедура во регионот. Во услови на недостиг на добро развиена трансплантација на бубрег од починати лица, нашиот тим воведе екстензивно користење живи дарители на бубрег со таканаречени проширени критериуми. Тоа подразбира прифаќање на дарители во постара и напредната возраст (над 65 години), несродни дарители (емоционално сродни), маргинални дарители и АБО инкомпатибилни дарители. Високото професионално ниво на хируршкиот, нефролошкиот и имунолошкиот клинички мониторинг овозможи уредно преживување на графтот и болниот со мал број компликации што кореспондира со развиените центри во светот. Оттаму авторите го препорачуваат користењето на дарителите со проширени критериуми како значаен извор на органи за трансплантација кое може да го ублажи недостигот на бубрези во целиот регион.

Клучни зборови: бубрежна трансплантација, проширени критериуми кај живи дарители, стапка на преживување на графтот и на пациентите, компликации. 